\title{
Castanea sativa; A Source of Turkish Propolis: Plant Anatomy, Palynology and Chemistry
}

\author{
Castanea Sativa; Türkiye Propolisi İçin Bir Kaynak: Bitki \\ Anatomisi, Palinolojisi ve Kimyası
}

\section{Research Article}

\author{
Ömür G. Çelemli'1,2, İlginç K. Temizer ${ }^{3}$, Golshan Zare', Kadriye Sorkun ${ }^{1,2}$ \\ 'Hacettepe University, Science Faculty, Department of Biology, Beytepe, Ankara, Turkey. \\ ${ }^{2}$ Hacettepe University Bee and Bee Products Applied and Research Center, Ankara, Turkey. \\ ${ }^{3}$ Giresun University, Vocational School of Health, Güre, Giresun, Turkey.
}

\section{ABSTRACT}

\begin{abstract}
n this study, we aimed to search the anatomical and palynological characteristics of Castanea sativa which is a botanical source for Turkish propolis. Within this context, we investigated the transverse section of leaf and stem of Castanea sativa. We observed palisade and spongy parenchyma, upper and lower epidermis, schlerenchyma and vascular bundles in the transverse section of the leaf by microscopic examination. We observed periderm, schlerencymatic tissue, secondary xylem, secondary phloem, vascular cambium and a parenchymatic pith in the tranverse section of the stem. By palynological analysis pollen grains are found radially symmetric, isopolar and tricolporate. Besides the microscopic analysis, the chemical content of Castanea sativa propolis was analysed by Gas Chromatography and Mass Spectrometry (GC-MS). Alcohols, aldehydes, aliphatic acids and their esters, carboxylic acids and their esters, cinnamic acids and their esters, flavonoids, hydrocarbons, and ketones were determined by chemical analysis of propolis ethanol extract. "Benzoic acid"was found in highest ratio $7.88 \%$ in the extract. The anatomical, palynological and chemical results of this study will be guide for further researchs about beekeeping and bee products in Turkey.
\end{abstract}

\section{Key Words}

Castanea sativa, anatomical, palynological, GC-MS.

\section{ÖZET}

u çalışma ile Türkiye propolisi için bitkisel bir köken olan Castanea sativa‘nın anatomik ve palinolojik karakterlerinin araştırılması amaçlanmıştır. Bu kapsamda, Castanea sativa bitkisinin yaprak ve gövde enine kesitleri incelenmiştir. Mikroskobik inceleme ile yaprak enine kesitinde palizat ve sünger parenkiması, üst ve alt epidermis, sklerenkima ve iletim demetleri gözlenmiştir. Gövde enine kesitinde ise periderm, sklerenkimatik doku, sekonder ksilem, sekonder floem, vaskular kambiyum ve parenkimatik öz gözlenmiştir. Palinolojik analiz ile polenin radyal simetrik, izopolar ve trikolporat olduğu belirtilmiştir. Mikroskobik analizlerin yanında, Castanea sativa propolisinin kimyasal içeriği gaz kromatografisi ve kütle spektrometresi (GC-MS) cihazı ile analiz edilmiştir. Propolisin etanol özütünün kimyasal analizi ile alkoller, aldehidler, alifatik asit ve esterleri, karboksilik asit ve esterleri, sinamik asit ve esterleri, flavonoidler, hidrokarbonlar ve ketonlar grubuna ait bileşikler tespit edilmiştir. "Benzoik asit" bileşiği \%7.88'lik oranla özütte en yüksek miktarda bulunan bileşiktir. Bu çalışmanın anatomik, palinolojik ve kimyasal analiz sonuçları Türkiye arıcılığı ve arı ürünleri ile ilgili ileriki çalışmalara ışık tutacaktır.

\section{Anahtar Kelimeler}

Castanea sativa, anatomik, palinolojik, GC-MS.

Article History: Received: Dec 24, 2015; Revised: Feb 24, 2016; Accepted: Feb 25, 2016; Available Online: Apr $01,2016$. DOI: $10.15671 /$ HJBC.20164417560

Correspondence to: Ö.G. Çelemli, Department of Biology, Faculty of Science, Hacettepe University, Ankara, Turkey. 


\section{INTRODUCTION}

Dropolis is the generic name for the resinous substance collected by honeybees (Apis mellifera) from various plant sources [1]. It is a sticky resinous hive product and used by bees as glue in general-purpose. The word "propolis" is derived from the Greek pro (before) and polis (city). Propolis was being used to make the protective shield at the entrance of beehive. It is also used to fill the cracks in the hive, to attach the corners of frames to the grooves in the hive, and to polish the cells of the honeycomb. The bodies of dead lizards, snakes and mice that die in hives are sealed into the walls with bee glue, thereby protecting the colonies against the unpleasant and bacterial flora of the putrefying corpses [2].

The first report on use of propolis as a folk medicine dates back to 300 B.C., and recently propolis has also been extensively used in food and beverages to improve health and prevent diseases [1].

This bee product has gained significant popularity in the last decades in alternative medicine, apitherapy, and the production of healthy foods and beverages due to its numerous biological activities [3].

The chemical composition of propolis is highly variable mainly due to the variability of plant species growing around the hive, from which the bees collect the exudates [4].

Honeybees collect material from partically any abundant plant source in the neighborhood of the hive, be it Populus, eucalyptus, pine, sugarcane, cashew nut or orange trees. Poplars (Populus spp.), birches (Betula sp.), pine trees (Pinus spp.), oaks (Quercus spp.), chesnut trees (Aesculus hippocastanum) and eucalyptus (Eucalyptus spp.) are among the more important resin sources in the northern hemisphere [5]. In the temperate zone of the world, the main source of bee glue is the resinous exudate of the buds of poplar trees, mainly the black poplar (Populus nigra). For this reason, European propolis contains typical poplar bud phenolics: flavonoid aglycones (flavones and flavanones), phenolic acids and their esters. Poplar trees are common only in the temperate zone; they cannot grow in tropical or subtropical regions. As a result, propolis from tropical regions, although highly diverse in its chemical composition, has a chemical profile different from that of the poplar type [6].

In the northern area of Russia propolis mainly comes from the exudate from birch buds (Betula verrucosa) and Populus tremula [7]; in Mediterranean regions from black poplars and from the leaves of Cistus spp. [8]; in Brazil from the leaves of some species of Baccharis dracunculifolia [9]; in Venezuella and Cuba from the floral resin of the genus Clusia [10].

Until now, a number of propolis types have been identified according to their chemistry and plant origin, the most popular being poplar (European) type propolis, Brazilian green propolis, and red propolis (Brazilian, Cuban, Colombia) [3].

The materials vailable to bees for "manufacturing" of propolis are produced by a variety of botanical processes in different parts of plants. According to Crane, substances actively secreted by plants and substances exuded from wounds in plants: lipophylic materials on leaves and leaf buds, mucilages, gums, resins, latices, etc. [11]. Forager bees produce propolis by mixing resins from plants with wax from their glands. Virtually all biologically active substances of propolis substances are components of its resin, so the composition of propolis thus depends on the plant sources of this resin. Bees from the same colony will visit plants from different species, but often there seems to be a marked preference for one or a few resin sources. This is exemplified by the chemogeographic patterns of propolis types [12].

Silici et al. (2007) described that the origin plants of Turkish propolis are Populus sp., Eucalyptus sp. and Castanea sativa. Chesnut (Castanea sativa) is a multipurpose species that is cultivated for its nuts and contributes positively to the forestry landscape. It is distributed mainly in the Northern Hemisphere, in Asia mostly in China, Korea and Japan, in Southern Europe from Turkey to Atlantic Islands and in the United States. Southern Europe and Turkey is the main area where $C$. sativa is predominant [5]. 
The present study aims to compare the anatomical and palynological characteristics of Castanea sativa in propolis and in plant. It aims also analyse the chemical composition of Castanea sativa propolis of nearby hives.

\section{MATERIALS AND METHODS Propolis Material}

Castanea sativa propolis sample was collected from Black Sea Region of Turkey. It was collected from the edges of frames and bottom board of the hive by scraping with a spatula.

\section{Plant Material}

Branch and leaf buds of Castanea sativa were collected in April 2014, from the Black Sea Region of Turkey.

\section{Anatomical Studies}

For anatomical investigations, specimens were kept in $70 \%$ ethanol. In anatomical analysis, cross sections of leaves, petiole, and leaves were prepared. Slides were observed with a Olympus CX21 microscope light microscope.

\section{Palynological Studies}

Pollen grains were obtained from the mature anthers of Castanea sativa. For light microscope (LM) investigation, pollen slides were prepared by glycerine gelatine with basic fuchsin according to the Wodehouse method (1935) [13]. Pollen were collected from mature flowers and they were put on an object slide and 2-3 drops of $96 \%$ ethyl alcohol were added to dissolve resin and fats on pollen grains. Then slides were heated at 30-40 ${ }^{\circ} \mathrm{C}$ to evaporate alcohol with a special care, in order not to separate exine and intine from each other. After evaporation of the alcohol, 1-2 mm3 of glycerin-gelatin with basic fucsin was added to the stuck pollen grains on the object slide. These object slides were heated on a $30-40^{\circ} \mathrm{C}$ heater to melt glycerin-gelatin. Then this was mixed by using a platinum pin to make pollen grains free from the object slide. Then it was covered with a cover glass and turned upside-down to make pollen grains close to upper surface, until glycerinegelatin freeze. The terminology used is of Punt et al. [14]. The polar axis (P), equatorial axis $(E)$, colpus length $(\mathrm{Clg})$, colpus width
(CIt), exine thickness (Ex), intine thickness (In), apocolpium diameter ( $\mathrm{t}$ ) and $\mathrm{AMB}$ diameter ( $\mathrm{L}$ ) were measured from 30 pollen grains of each specimen under Olympus CX21 microscope by using an immersion objective lens (x100).

\section{Chemical Analysis of Propolis Samples}

The collected propolis samples were frozen in the fridge, crushed into pieces and then weighed 30 $\mathrm{g}$ was mixed with $96 \%$ ethanol in a ratio of $1 \mathrm{~g}$ : $3 \mathrm{~mL}(\mathrm{w} / \mathrm{v})$ and then sealed in a bottle at $30^{\circ} \mathrm{C}$ for two weeks. After two weeks, the supernatant was filtered twice with Whatman No. 4 and No.1 filter paper, respectively. The final solution, called Ethanol Extracts of Propolis (EEP) was evaporated until complete dryness. About $5 \mathrm{mg}$ of dry substance were mixed with $75 \mu$ l of dry pyridine and $50 \mu \mathrm{l}$ bis (trimethylsilyl) trifluoroacetamide (BSTFA) heated at $80^{\circ} \mathrm{C}$ for $20 \mathrm{~min}$ and then the final supernatant was analysed by GCMS [15].

A GC 6890N instrument from Agilent (Palo Alto, CA, USA) coupled with a mass detector (MS5973; Agilent) was used for the analysis of propolis sample. Experimental conditions of the GC-MS system were as follows: a DB 5MS column (30 $\mathrm{m} \times 0.25 \mathrm{~mm}, 0.25 \mu \mathrm{m}$ film thickness) was used and the flow rate of the mobile phase $(\mathrm{He})$ was set at $1 \mathrm{ml} / \mathrm{min}$. In the GC part, temperature was kept for $8 \mathrm{~min}$ at $35^{\circ} \mathrm{C}$ and then increased to $60^{\circ} \mathrm{C}$ at $6^{\circ} \mathrm{C} / \mathrm{min}$ intervals followed by $4^{\circ} \mathrm{C} / \mathrm{min}$ to $160^{\circ} \mathrm{C}$ and $20^{\circ} \mathrm{C} / \mathrm{min}$ to $200^{\circ} \mathrm{C} / \mathrm{min}$ and kept at $200^{\circ} \mathrm{C}$ for $1 \mathrm{~min}$.

Organic compounds in propolis samples were identified in Wiley's NIST Mass Spectral Library, if the obtained comparison scores were higher than $95 \%$. Otherwise, fragmentation peaks of the compounds were evaluated, and the compounds were identified using the memory background for the identification of the compounds that appeared in GC-MS chromatograms. Contents of individual compounds in the ethanol extract are given in percent of the total compounds in the sample. This was the standard way to quantify most organic compounds in the honeysamples. Variations were not higher than $5 \%$. 


\section{RESULTS}

\section{Chemical Analysis of Castanea sativa Propolis}

We found the compounds belong to the alcohols (7.64\%), aldehydes (1.25\%), aliphatic acids and their esters (4.63\%), carboxylic acids and their esters $(9.76 \%)$, cinnamic acids and their esters (0.32\%)flavonoids (6.9\%), hydrocarbons $(3.47 \%)$, ketones $(0.98 \%)$ group by GC-MS analysis (Table 1).

The mesophyll chesnut leaves were heterogeneous and asymmetrical due to the presence of palisade parenchyma in upper surface and spongy parenchyma on lower surface. We observed both palisade and spongy parenchyma with 2-3 layers, upper and lower epidermis has only one layer was observed (Figure 1).

Table 1. Chemical composition of ethanol extract of Castanea sativa propolis sample (\% of total area of the peak).

\begin{tabular}{|c|c|}
\hline Compounds & $\begin{array}{c}\text { Castane } \\
\text { sativa }\end{array}$ \\
\hline \multicolumn{2}{|l|}{ propolis } \\
\hline Alcohols & $\%$ \\
\hline $\begin{array}{l}\text { 2-Naphthalenemethanol, } \\
\text { 1,2,3,4,4a,5,6,8a-octahydro-. } \\
\text { alpha.,.alpha.,4a,8-tetramethyl-, [2R-(2. } \\
\text { alpha.,4a.alpha.,8a.beta.)] }\end{array}$ & 4.62 \\
\hline 3-Buten-1-ol, 3-methyl- & 0.06 \\
\hline Benzenemethanol (CAS) & 2.32 \\
\hline Benzenemethanol-3-hydroxy & 0.52 \\
\hline 2-Buten-1-ol, 3-methyl- & 0.1 \\
\hline 2,6-dichlorobenzyl alcolhol & 0.02 \\
\hline Total & 7.64 \\
\hline \multicolumn{2}{|l|}{ Aldehydes } \\
\hline Benzaldehyde (CAS) & 0.14 \\
\hline Benzaldehyde, 4-methyl- & 0.02 \\
\hline 1,2-Benzenedicarboxaldehyde(CAS) & 0.58 \\
\hline 3-methoxy-4-hydroxy-benzaldehyde & 0.35 \\
\hline 2-methyl-4,5-dihidroxybenzaldehyde & 0.16 \\
\hline Total & 1.25 \\
\hline \multicolumn{2}{|l|}{ Aliphatic acids and their esters } \\
\hline Ethyl Oleate (Oleic acid,ethyl ester) & 0.78 \\
\hline
\end{tabular}

\begin{tabular}{|c|c|}
\hline Hexadecanoic acid, ethyl ester & 0.31 \\
\hline $\begin{array}{l}\text { Octadecanoic acid, ethyl ester (Stearic } \\
\text { acid, ethyl ester) }\end{array}$ & 2.57 \\
\hline Linoleic acid ethyl ester & 0.12 \\
\hline 2-butenoic acid, 2-methyl-, (E)- & 0.06 \\
\hline 2-propenoic acid, 3-phenyl- (CAS) & 0.79 \\
\hline Total & 4.63 \\
\hline \multicolumn{2}{|l|}{ Carboxylic acids and their esters } \\
\hline Acetic acid & 019 \\
\hline Acetic acid, phenoxy-', methyl ester & 0.06 \\
\hline Benzoic acid, ethyl ester & 0.10 \\
\hline Benzoic acid, 2,5-dimethyl & 0.36 \\
\hline $\begin{array}{l}\text { 1,2-Benzenedicarboxylik asit,diisooctyl } \\
\text { ester }\end{array}$ & 1.15 \\
\hline Benzoic acid & 7.88 \\
\hline $\begin{array}{l}\text { CIS-3- } \\
\text { CHLOROCYCLOBUTANECARBOXYLIC } \\
\text { ACID, METHYL ESTER }\end{array}$ & 0.02 \\
\hline Total & 9.76 \\
\hline \multicolumn{2}{|l|}{ Cinamic acids and their esters } \\
\hline Benzyl cinnamate & 0.32 \\
\hline Total & 0.32 \\
\hline \multicolumn{2}{|l|}{ Flavonoids } \\
\hline $\begin{array}{l}\text { 2-Propen-1-one, 1-(2,6-dihydroxy-4- } \\
\text { methoxyphenyl)-3-phenyl-, E }\end{array}$ & 3.28 \\
\hline $\begin{array}{l}\text { 4H-1-Benzopyran-4-one, 2,3-dihydro-5,7- } \\
\text { dihydroxy-2-phenyl(Pinocembrin) }\end{array}$ & 1.09 \\
\hline $\begin{array}{l}\text { 4H-1-Benzopyran-4-one, 5-hydroxy-7- } \\
\text { methoxy-2-phenyl }\end{array}$ & 2.53 \\
\hline Total & 6.9 \\
\hline \multicolumn{2}{|l|}{ Hydrocarbons } \\
\hline Octadecane & 0.53 \\
\hline Z-14-Nonacosane & 0.7 \\
\hline Heptacosane & 1.24 \\
\hline 1-Docosene & 0.51 \\
\hline Styrene & 0.10 \\
\hline Heneicosane & 0.39 \\
\hline Total & 3.47 \\
\hline \multicolumn{2}{|l|}{ Ketones } \\
\hline Ethanone, 1-phenyl- & 0.98 \\
\hline Total & 0.98 \\
\hline
\end{tabular}


Ö.G. Çelemli et al. / Hacettepe J. Biol. \& Chem., 2016, 44 (1), 7-14 $\mid 11$

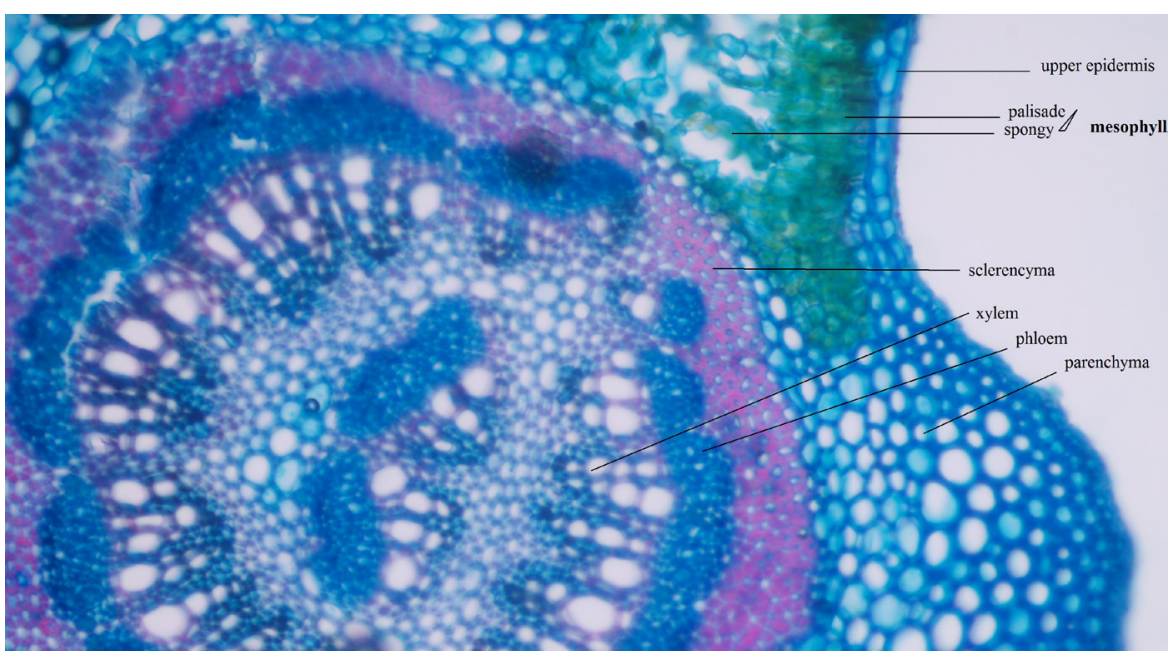

Figure 1. Transverse section of Castanea sativa leaf.

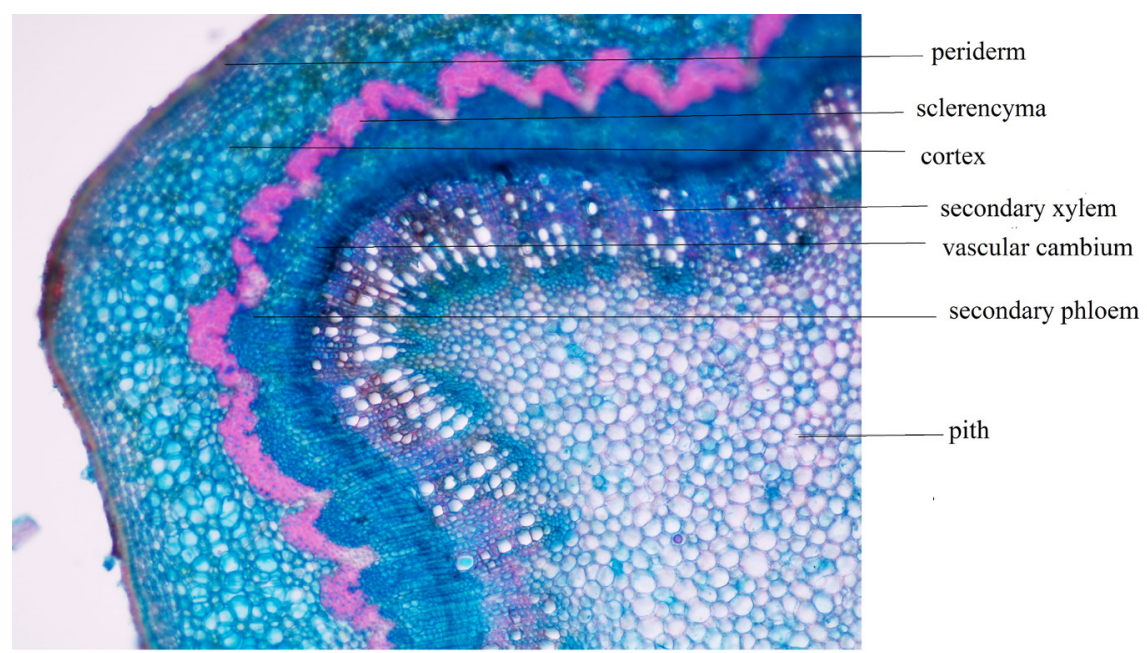

Figure 2. Transverse section of Castanea sativa stem.

\section{Stem Anatomy}

Weobserved periderm with 5-10layers, parechymatic tissue with 8-10 layers, schlerencymatic tissue around the secondary phloem and a parenchymatic pith at the center (Figure 2).

\section{Pollen Characteristics}

Light microscopy (LM) observations with measurements were made on pollen from mature anthers which have been prepared according to the Wodehouse method (Wodehouse 1935). Measurements of different parts of the pollen such as size of pollen, colpi diameter, distance between two colpi and exine thickness were taken using an immersion object-lens (x100) and a scale ocular (10x). These measurements were made on about 30 pollens for equatorial view, 20 pollens for polar view.

The pollen grains are found radially symmetric, isopolar, tricolporate. The shape is prolate [the term according to Erdtman (1969) based on the P/E ratio (1.37)], with polar axes ranging from 12 to $16 \mu \mathrm{m}$, mean $14.70 \pm 1.14$ and equatorial axes from 10 to 13 $\mu \mathrm{m}$, mean $10.70 \pm 1.08$ respectively. In polar view, the pollen grains are circular, amb diameter is between 11-14 $\mu \mathrm{m}$ and mean $12.20 \pm 1.10$. The apocolpial area is wide, distance between colpi ends is $8.50 \pm 1.14$ $\mu \mathrm{m}$. The colpi are long and with distinct margin, Clg $11.03 \mu \mathrm{m}$, Clt $0.8 \mu \mathrm{m}$. The pori are circular and with distinct margin, Plg $3.43 \mu \mathrm{m}$, Plt $3.63 \mu \mathrm{m}$. The exine is $1 \mu \mathrm{m}$ thick. The exine ornamentation in light microscope is psilate (Table 2). 


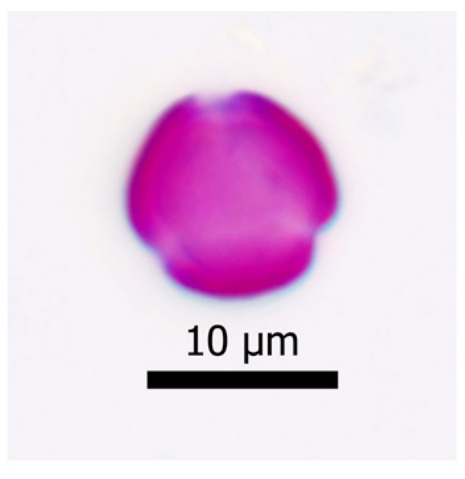

a.

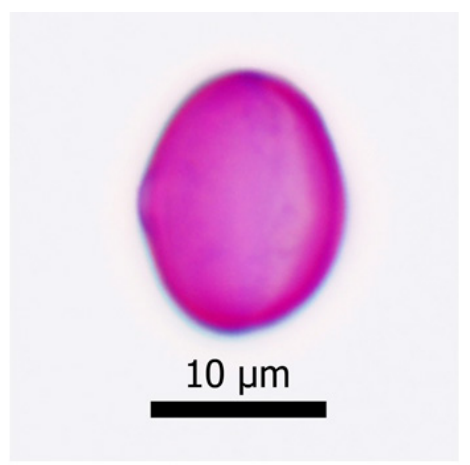

b.

Figure 3. Light microscope micrographs of pollen of Castanea sativa (a.polar view of pollen, b.equitorial view of pollen)

Table 2. Pollen morphological features of the Castanea sativa (P: polar axis, E: equatorial axis, Clg: colpus length, Clt: colpus width, t: apocolpium).

\begin{tabular}{|c|c|}
\hline Pollen characteristics & Castanea sativa \\
\hline Pollen shape & Prolate \\
\hline $\mathbf{P}(\mu \mathrm{m})$ & $12-16$ (mean:14.70 \pm 1.14$)$ \\
\hline$E(\mu \mathrm{m})$ & $10-13 \mu \mathrm{m}$ (mean: $10.70 \pm 1.08$ ) \\
\hline P/E & 1.37 \\
\hline AMB $(\mu \mathrm{m})$ & 11-14 (mean: $12.20 \pm 1.10)$ \\
\hline Exine $(\mu \mathrm{m})$ & 1 (mean: $1 \pm 0$ ) \\
\hline $\operatorname{Clg}(\mu \mathrm{m})$ & 9-14 (mean: 11.03 \pm 1.79 ) \\
\hline Clt $(\mu \mathrm{m})$ & 0.5-2 (mean: $0.8 \pm 0.44$ ) \\
\hline $\mathbf{T}(\mu \mathrm{m})$ & 5-9 (mean: $8.5 \pm 1.14)$ \\
\hline $\operatorname{PIg}(\mu \mathrm{m})$ & 3-4 (mean: $3.4 \pm 0.5)$ \\
\hline $\operatorname{PIt}(\mu \mathrm{m})$ & 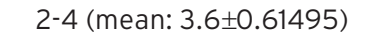 \\
\hline Plg/PIt & 0.94 (Oblate spheroidal) \\
\hline Pollen type & 3-colporate \\
\hline
\end{tabular}

\section{DISCUSSION}

Castanea sativa (Fagaceae) is a species of chesnut native in southeastern Europe and Asia Minor. Chesnut leaves are used in traditional medicine in the treatment of several diseases, such as bronchitis and cough. 1,1-Diphenyl-2-picryl hydrazyl (DPPH) scavenging activity against superoxide anion and hydroxyl radicals, was previously reported for C.sativa leaves. Such antioxidant activity was suggested to be related with phenolic composition. Rutin, hesperidin, quercetin, apigenin, morin, galangin, kaempferol and isoquercitrin have been identified in C.sativa leaves [16].
Moreira et al. (2008) conducted pollen analysis, total phenols content and antioxidant activity. They found propolis sample which contains mostly Castanea sativa (45\%) pollen, showed the highest values of total phenols in comparison to the sample which contains mostly Populus tremula (50\%) pollen. Chesnut propolis presented a very high concentration of total phenols and also a strong scavenging activity against DPPH radicals [17]. According to our results, $6.9 \%$ of flavonoids were found in Castanea sativa propolis. This value is not so high but it can be enough for antioxidant activity. 
Kolankaya et al., 2002 investigated the chemical composition and protective effect of Turkish Castanea sativa propolis against alcohol induced oxidative stress. They found aliphatic acids (2.22\%), alcohols (1.71\%), aromatic acids and their esters (14.62\%), flavanones and flavones (31.8\%), ketones (24.7\%) and terpenoinds (4.50\%) in the analyzed propolis sample. They found the flavonoids as galangin, quercetin, kaempferol apigenin, pinobanksin, pinocembrin and pinostobin. They also found that propolis caused an increase in HDL level and decrease in LDL level [18]. Similiar to this research we found pinocembrin in investigated chesnut propolis.

Silici et al., (2007), found fatty and aliphatic acids (butanedioic acid), sugars ( $\alpha$-D-Galactofuranose, -DL-Lyxofuranoside, D-Fructose, D-Mannose, D-Galactose) phenolic compounds (3,5-Dimethoxy4-hydroxyphenyl glucoside, Galangin) and the other compounds (Bromochloromethane, 3,9-Diphenyl8-carbethoxyimidazoquinoline, Spifofuran, Benzazulene,1,8-Dihydroxy-3-methylanthraquinone, 6-Methyl-14H-benzocycloheptanaphtho-14-one, 1,1-Biphenyl-4-carbonitrile, TMS ether of glycerol, 10-Ethynl-10-hydroxy-1,8-diphneyl-anthracenone) in chesnut propolis [5].

Dias et al., (2012) investigated the Populus sp. Pinus sp., Quercus sp., Castanea sativa propolis according to their, pollen, chemical content and microbiological effects. They found that Quercus sp. and Castanea sativa propolis have higher content of phenolic compounds and flavonoids than the Populus sp. and Pinus sp. samples [4]. We also found the flavonoid compounds higher compared to the other compounds identified in the chesnut propolis.

Alissandrakis et al. (2011) investigated the chesnut honey and extracts of chestnut flowers. They found benzyl alcohol, 1-phenylethanol, acetophenone, linalool, nonanal, phenylethyl alcohol, cis-pyranoid linaloxide, octanoic acid, benzoic acid, methyl salicylate, nonanoic acid, caracrol, (Z)-8Hydroxylinalool, (E)-8-Hydroxylinalool, o-Anisic acid in flowers extracts [19]. Among these compounds that have been identified from chesnut flowers, only benzoic acid is the only common compound identified from chesnut propolis.
Sáez et al., (2012) researched the characteristics of leaf anatomy of in vitro cultured microshoot and nursery plant leaves of C.sativa. They found the total parenchyma width $88.73 \pm 1.69 \mu \mathrm{m}$, palisade parenchyma $14.55 \pm 0.45 \mu \mathrm{m}$, spongy parenchyma $51.90 \pm 2.55 \mu \mathrm{m}$, upper epidermis $9.96 \pm 0.40 \mu \mathrm{m}$, lower epidermis $9.10 \pm 0.30$ in microshoots. They also found these parameters in nursery plants as 109.63 $\pm 1.79 \mu \mathrm{m}, 33.550 .71 \mu \mathrm{m}, 48.85 \pm 2.17$ $\mu \mathrm{m}, 18.63 \pm 3.08 \mu \mathrm{m}, 13.56 \pm 0.59 \mu \mathrm{m}$ respectively. [20]. Similiar to this research we observed palisade parenchyma in upper surface and spongy parenchyma on lower surface. We observed both palisade and spongy parenchyma have three layers, while upper and lower epidermis have only one layer.

Pinto et al. (2011) were investigated the Castanea sativa leaves and they had observed the upper epidermis as two layers and lower epidermis as a single layer. We observed upper and lower epidermis has only one layer [21]

Pehlivan (1995) and Paldat (2015) confirmed that the pollen morphologies of Castanea sativa are essentially the same [22,23]. Tüylü and Sorkun (2007) found the pollen shape as subprolate [24]. But according to our measurements and paldat (2015) it is observed as prolate [23].

Castanea sativa is an important plant for beekeeping in Turkey. Since it is a potential source for propolis and honey. Therefore it is important to recognize this species and anatomically, palynologically and chemically. There is not any detailed research about anatomy of Castanea sativa in literature. By this study the anatomy, palynology of Castanea sativa and the chemical composition of Castanea sativa propolis were investigated together.

\section{References}

1. Y.K. Park, S.M. Alencar, C.L. Agular, Botanical Origin and Chemical Composition of Brazilian Propolis, J. Agric. Food Chem., 50 (2002) 2502-2506.

2. N. Kumar, M. Ahmad, R. Dang, A. Husain, Antioxidant and antimicrobial activity of propolis from Tamil Nadu zone, Journal of Medicinal Plants Research, 2 (2008) 361-364.

3. M. Popova, B. Trusheva, S. Cuatajar, D. Antonova, D. Mifsud, C. Farrugia, V. Bankova, Identification of the plant origin of the botanical biomarkers of mediterranean type propolis, Natural Product Communications, 7 (2012) 569-570. 
4. L.G. Dias, A.P. Pereira, L.M. Estevinho, Comparative study of different Portuguese samples of propolis: Pollinic, sensorial, physicochemical, microbiological characterization and antibacterial activity, Food and Chemical Toxicology, 50 (2012) 4246-4253.

5. S. Silici, M. Ünlü, G.V. Ünlü, Antibacterial activity and phytochemical evidence fort he plant origin of Turkish propolis from different regions, World J Microbiol Biotechnol., 23 (2007) 1797-1803.

6. V. Bankova, Recent trends and important developments in propolis research, eCAM 2 (2005) 29 - 32.

7. F. Farre, I. Frasquet, A. Sanchez, Propolis and human health, Ars Pharmaceutica, 45 (2004) 21.

8. I. Martos, M. Cossentini, F. Ferreres, F.A. TomasBarberan, Flavonoid composition of Tunisian honeys and propolis, J. Agric. Food Chem., 45 (1997) 2824.

9. S. Kumazawa, S.M. Yoneda, I. Shibata, J. Kanaeda, T. Hamasaka, T. Nakayama, Direct evidence fort he plant origin of Brazillian propolis by the observation of honeybee behavior and phytochemical analysis, Chem Pharm. Bull., 51 (2003) 740.

10. O. Cuesta-Rubio, B. Frontana-Uribe, T. Ramirez-Apan, J. Cardenas, Polyisoprenylated Benzophenones in Cuban Propolis; Biological Activity of Nemorosone, Z Naturforsch, 57 (2002) 372.

11. V.S. Bankova, S.L. Castro, M.C. Marcucci, Propolis: recent advances in chemistry and plant origin, Apidologie, 31 (2000) 3-15.

12. A. Salatino, C.C. Fernandes-Silva, A.A. Righi, M.L.F. Salatino, Propolis research and the chemistry of plant products, Nat. Prod. Rep., 28 (2011) 925-936.

13. R.P. Wodehouse, Pollen grains, McGraw Hill Book Company, New York, (1935) 574 pp. \& 14 planchas.

14. W. Punt, P.P. Hoen, S. Blackmore, S. Nilsson, A. Le Thomas, Glossary of pollen and spore terminology, Rew Palaeobot Palyno, 143 (2007) 1-81.

15. I.F. Almeida, P.C. Costa, M. F. Bahia , Evaluation of Functional Stability and Batch-to-Batch Reproducibility of a Castanea sativa Leaf Extract with Antioxidant Activity, AAPS Pharm. Sci. Tech., 11 (2010) 120-125.
16. Ö. Gençay, B. Salih, GC-MS Analysis of Propolis Samples From Different Regions of Turkey, Four Different Regions of Brazil and One From Japan, Mellifera, 9-17 (2009) 19-28.

17. L. Moreira, L.G. Dias, J.A. Pereira, L. Estevinho, Antioxidant properties, total phenols and pollen analysis of propolis samples from Portugal, Food and Chemical Toxicology, 46 (2008) 3482-3485.

18. D. Kolankaya, G. Selmanoğlu, K. Sorkun, B. Salih, Protective effects of Turkish propolis on alcoholinduced serum lipid changes and liver injury in male rats, Food Chemistry, 78 (2002) 213-217.

19. E. Alissandrakis, P.A. Tarantilis, C. Pappas, P.C. Harizanis, Investigat,on of organic extractives from unifloral chesnut (Castanea sativa L.) and eucalyptusm (Eucalyptus globulus Labill.) honeys and flowers to identification of botanical marker compounds, Food Science and Technology, 44 (2011) 1042-1052.

20. P.L. Sáez, L.A. Brao, K.L. Sáez, M.S. Olate, M.I. Latsague, D.G. Ríos, Phytosentetic and leaf anatomical characteristcs of Castanea sativa: a comparison between in vitro and nursery palnts, Biologia Plantarum, 56 (2012) 15-24.

21. T.M. Pinto, N.M. Martins, J.G. Laranjo, J.F. Cardoso, F. Peixoto, Structural analysis of Castanea sativa Mill. Leaves from different regions in tree top, Brazilian Archives Of Biology and Technology, 54 (2011) 117-124.

22. S. Pehlivan, Türkiye'nin Alerjen Polenleri Atlası, (1995) $191 \mathrm{p}$.

23. https://www.paldat.org/(2015)

24. A. Tüylü, K. Sorkun, The Investigation of Morphologic Analysis of Pollen Grains Which are Economically Important and Collected by Apis mellifera L., Hacettepe J. Biol. \& Chem., 35 (2007) 31-38. 